\title{
Effects of Biochar, Plant Density and Spacing on Growth and Yield of Rice in a Tropical Inland Valley Swamp
}

\author{
Hindolo Andrew Bebeley ${ }^{1}$, Prince Tongor Mabey ${ }^{2, *}$, Prince Emmanuel Norman ${ }^{3}$ \\ ${ }^{1}$ Land, Water and Environmental Research Centre, Sierra Leone Agricultural Research Institute (SLARI), Freetown, Sierra Leone \\ ${ }^{2}$ Forestry Division, Ministry of Agriculture and Forestry, Freetown, Sierra Leone \\ ${ }^{3}$ Njala Agricultural Research Centre (NARC), Sierra Leone Agricultural Research Institute (SLARI), Freetown, Sierra Leone
}

\section{Email address:}

ptmabey@yandex.com (P. T. Mabey)

${ }^{*}$ Corresponding author

\section{To cite this article:}

Hindolo Andrew Bebeley, Prince Tongor Mabey, Prince Emmanuel Norman. Effects of Biochar, Plant Density and Spacing on Growth and Yield of Rice in a Tropical Inland Valley Swamp. International Journal of Applied Agricultural Sciences. Vol. 7, No. 2, 2021 , pp. $77-83$. doi: $10.11648 /$ j.ijaas.20210702.11

Received: February 13, 2021; Accepted: February 23, 2021; Published: March 10, 2021

\begin{abstract}
Biochar has been confirmed to boost soil fertility and crop efficiency. The study aimed to examine the impacts of different combinations of biochar, plant hill and spacing on the growth and yield parameters of rice (Oryza sativa L.) var NERICA L 19 in an inland valley swamp in Sierra Leone. The experiment was performed in a Randomized Complete Block Design using eight treatment combinations including: two levels of Biochar-soil mixtures $\left(10 \mathrm{tha}^{-1}\right.$ and $\left._{0} \mathrm{t} \mathrm{ha}^{-1}\right)$, two levels of plant density per hill ( 1 seedling per hill and 2 seedlings per hill), and two levels of plant spacing $(25 \mathrm{~cm}$ and $20 \mathrm{~cm})$. Growth parameters were conducted at 4, 6, 8, and 10 weeks after transplanting (WAT), while yield parameters were measured at harvest. Biochar hill and spacing had no significant effect on plant height, leaf area, grain yield, straw yield, and harvest index, but biochar plant spacing had a significant effect on tiller number. Biochar significantly enhanced plant growth (tiller number) and yield attribute traits such as panicle number and straw yield. The potential of gliricidia biochar in supporting increased growth and yield suggest its exploitation for both straw and grain yield productivity of rice in the IVS. Residual gliricidia biochar could be also exploited in future studies to determine their benefit in enhancing grain yield in IVS rice.
\end{abstract}

Keywords: Biochar, Grain Yield, Density, Rice Straw, Panicle Number, Spacing

\section{Introduction}

Rice (Oryza sativa L.) is the world's essential food crop, as it supports millions of livelihoods in Africa and some parts of Asia [1-3]. It is the most important staple food in Sierra Leone. However, the productivity of the crop lags behind its supply, thereby contributing to food insecurity in the country. Moreover, the Global Hunger Index (GHI) of Sierra Leone estimates 38.3 scores, which falls within the 119 countries with highest GHI ranging from 35.0-49.9 scores [4]. The decreased productivity of rice is partly due to infertile soils and the influence by climate change involving changes in rainfall and temperature levels that impede its growth and yield $[5,6]$. To resolve this menace, a sustainable novel technology known as biochar has been suggested to be effective in increasing and conserving soil fertility as well as mitigating climate change [7].

Biochar is a black carbon-rich solid material produced by heating biomass $\left(250-700^{\circ} \mathrm{C}\right)$ in an oxygen-limited environment known as pyrolysis [7]. Biochar amendment to soils is regarded as a way of combating climate change through the sequestration of carbon (C) [8]. Though biochar has been used for decades to improve crop yields, concern in biochar has grown recently, especially for its advantages in environmental or carbon restoration. Studies have shown that biochar amendment can mitigate climate change, modify soils, and improve crop productivity $[9,10]$.

Nonetheless, biochar application has shown some different effects, depending on soil conditions, feedstock from biochar, temperature from biochar pyrolysis, and other environmental conditions. There are several possible useful features related to biochar use as a soil amendment, such as improved soil nutrient supply to crops [11], enhanced inorganic and organic 
fertilizer use capacity [12], minimized loss of nutrients and demand for fertilizers [13], increased soil properties (soil water retention efficiency, bulk density, porosity, infiltration intensity, soil aeration, and aggregate stability [14], substantial metal stabilization and decreased bioavailability of plants grown in contaminated soils [15], improved crop growth and efficiency [16], decreased salinity, heat stress and drought effects on soil and plant growth [17]. Also, a metaanalysis by Liu et al. [18] showed the benefits of biochar amendment $\left(<30 \mathrm{t} \mathrm{ha}^{-1}\right)$ on crop yield, with an average mean increase of $11 \%$.

While the environmental benefits of the use of biochar has gained significant attention, their impact on agriculture has been uncertain and somehow contradictory. Biochar can therefore, be processed using a diverse range of feedstocks, produced at varying temperature pyrolysis, introduced at various particles and the time of application according to the growth and development stages of the crop. Thus, different plants may also react in different ways to the use of biochar. Biochar research at various temperatures suggest that their influence on $\mathrm{N}$ absorption by Rocket (Eruca sativa L.) [19], and on the growth of lettuce (Lactuca sativa L.) [20] Varies. On the one hand, biochar has been observed to trigger microbial action [21], which causes soil organic matter loss, while, on the other hand, data analyzes also show that the usage level of biochar above 55 tons hectare ${ }^{-1}$ can lead to a decline in crop yield $[22,23]$.

In the tropics, where unsustainable agricultural practices such as slash-and-burn agriculture remains the dominant mode of cultivation [24], soil fertility is usually exhausted after planting as a result of slash-burn shifting cultivation [25-27]. Hence, this form of agricultural practice contributes to over $60 \%$ of the world's deforestation [28]. While many scholars have examined the influence of biochar on soil biological and chemical factors, limited research has examined the impact of biochar on crop growth and yield, especially in this part of the world. Therefore, this study aimed to assess the effects of biochar amendment, plant density and spacing on rice growth and yield in an inland valley swamp in Njala University, Sierra Leone.

\section{Materials and Methods}

\subsection{Site Description}

The experiment was conducted at Njala University, Njala Campus in Kori Chiefdom, Moyamba District, in Southern Sierra Leone. The University is about $67 \mathrm{~km}$ from Bo, the second capital of Sierra Leone, and is located on Latitude $8^{\circ}$ $\mathrm{N}$ and Longitude $12^{\circ} \mathrm{W}$. The climatic condition is tropical and is characterized by two main seasons; a rainy season (May to October) and a dry season (November to April). The average annual rainfall is about $2500 \mathrm{~mm}$, and the mean annual temperature ranges from a minimum of $27^{\circ} \mathrm{C}$ to a maximum of $33^{\circ} \mathrm{C}$. The research was conducted during the rainy season in an Inland Valley Swamp (IVS) situated at the experimental site of the University. The soil from the experimental site is clayey and classified as Vertisol (from the Twelve Soil Order).

\subsection{Biochar Preparation}

Gliricidia (Gliricidia sepium (Jacq.) Kunth ex Walp.) biomass was used for biochar production because of its tremendous ability to fix nitrogen in the soil. The gliricidia biomass was collected from a nearby research institution about $0.28 \mathrm{~km}$ away and transported to the experimental site. The biomass was allowed to dry before pyrolysis in an Elsa Stove of height $90 \mathrm{~cm}$ and a diameter of $55 \mathrm{~cm}$ (Figure 1). After pyrolysis, the biochar was allowed to dry before grinding using a mortar and pestle, and then the grounded biochar was dried and put into bags for later use.

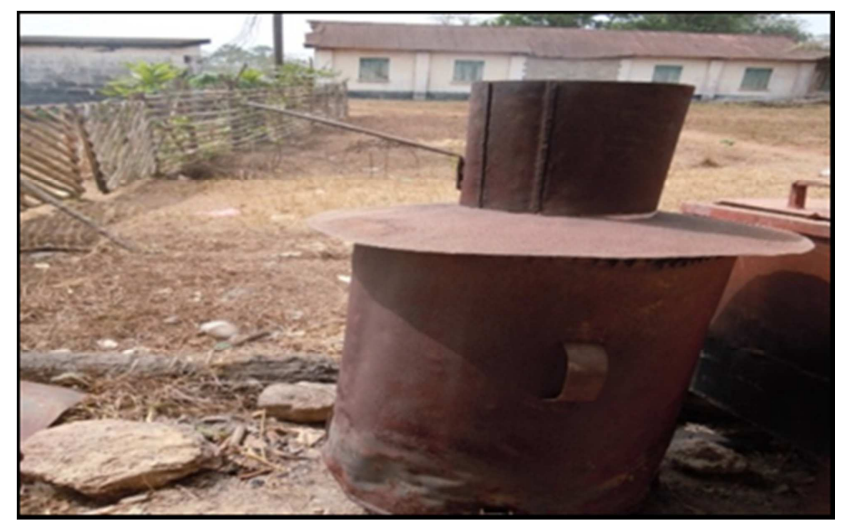

Figure 1. A digital photo of the locally-built Elsa Stove used to pyrolyze the Forest Lilac biomass used as biochar in the experiment.

\subsection{Land preparation, Experimental Layout and Design}

The experimental site preparation included site clearing, plowing, and puddling using simple farm tools like cutlasses, hoe, and shovel. The experiment was conducted from June to November 2018. The plot area was $41.9 \mathrm{~m} \times 11.9 \mathrm{~m}$ and was surrounded by bunds to regulate the water regime. The experiment laid out in a randomized complete block design. A total of eight treatment combinations comprising two levels of biochar-soil mixtures $\left(10 \mathrm{t} \mathrm{ha}^{-1}\right.$ and $\left.0 \mathrm{t} \mathrm{ha}^{-1}\right)$, two levels of plant density per hill (1 seedling per hill and 2 seedlings per hill), and two levels of plant spacing $(25 \mathrm{~cm}$ and $20 \mathrm{~cm}$ ) (Table 1).

Table 1. Treatments with a different combination of biochar, plant density, and spacing randomly allocated at different study plots.

\begin{tabular}{ll}
\hline Treatments & Combination of biochar, plant density, and spacing \\
\hline $\mathrm{T}_{1}$ & Biochar $\left(10 \mathrm{tha}^{-1}\right)+$ Density $(1)+$ Spacing $(20 \mathrm{~cm})$ \\
$\mathrm{T}_{2}$ & Biochar $\left(10 \mathrm{tha}^{-1}\right)+$ Density $(1)+$ Spacing $(25 \mathrm{~cm})$ \\
$\mathrm{T}_{3}$ & Biochar $\left(10 \mathrm{tha}^{-1}\right)+$ Density $(2)+$ Spacing $(20 \mathrm{~cm})$ \\
$\mathrm{T}_{4}$ & Biochar $\left(10 \mathrm{tha}^{-1}\right)+$ Density $(2)+$ Spacing $(25 \mathrm{~cm})$ \\
$\mathrm{T}_{5}$ & Biochar $\left(0 \mathrm{tha}^{-1}\right)+$ Density $(1)+$ Spacing $(20 \mathrm{~cm})$ \\
$\mathrm{T}_{6}$ & Biochar $\left(0 \mathrm{tha}^{-1}\right)+$ Density $(1)+$ Spacing $(25 \mathrm{~cm})$ \\
$\mathrm{T}_{7}$ & Biochar $\left(0 \mathrm{tha}^{-1}\right)+$ Density $(2)+$ Spacing $(20 \mathrm{~cm})$ \\
$\mathrm{T}_{8}$ & Biochar $\left(0 \mathrm{tha}^{-1}\right)+$ Density $(2)+$ Spacing $(25 \mathrm{~cm})$ \\
\hline
\end{tabular}

Plant density $=$ number of rice seedlings transplanted per hole; $1=$ one seedling and $2=$ two seedlings 


\subsection{Plant Material and Culture Management}

NERICA L 19 is a variety of the African NERICA varieties that was developed by the West African Rice Development Association in 1994 (WARDA), which is suitable for rainfed lowland ecology. Seedbeds were prepared, and the seeds were broadcasted. At 21 days after sowing (DAS), germinated seedlings were transplanted from the nursery bed to the experimental plots based on the various treatment combinations on the $4^{\text {th }}$ of July, 2018. Gap fillings were done four days after transplanting to uphold the required rice plants per hill in the experimental plots. The recommended doses of nitrogen, phosphate, and potassium fertilizer (NPK) 40-40-40 at $266.67 \mathrm{~kg} \mathrm{ha}^{-1}$ were applied. Weeding and pest control measures were carried out according to the requirement of the crop. The paddy field was managed from the grain-filling stage through to the maturing phase with regulated irrigation. The field was drained entirely two weeks before harvesting, and the plant was harvested using sickles.

\subsection{Data Collection}

Data were obtained for varying growth and yield parameters of the NERICA L 19 rice plant, including plant height, tiller number, leaf area, dry matter yield, biological yield, harvest index, and grain yield which was tagged per plot at random at 4, 6, 8 and 10 WAT. All the parameters were estimated at hill-scale (Figure 2). Measurements at the time of harvest focused on yield variables, which included the number of grains per panicle, number of tillers per hill, harvest index, seed weight, and grain yield.

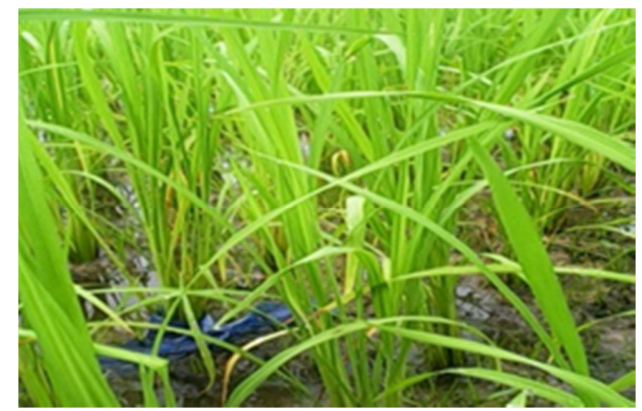

Figure 2. Rice hills and tillers of rice plants at biochar treated plot; source: by author.

\subsection{Statistical Analysis}

General Linear Factorial Model Analysis of Variance (three-way ANOVA) was used to evaluate the statistical significance of the effects of the biochar treatment as influenced by plant density and spacing on rice growth and yield. Post hoc comparisons were done using the least significant difference (LSD) test, with statistical significance requirement being set at $\mathrm{P}<0.05$. Simple linear regression analysis was performed to determine the relationship between related growth yield parameters at the 5\% level of significance. Data analyses were done using Microsoft Excel and GenStat. Statistical Software version 19.1.

\section{Results and Discussion}

\subsection{Growth Parameters}

Treatment and sampling regime (WAT) significantly $(\mathrm{P}<0.001)$ influenced plant height, number of tillers per hill and leaf area (Figures 3-5). Treatment B0H2S25 exhibited the tallest plants $(91 \mathrm{~cm})$, followed by Treatment B10H1S25 $(89 \mathrm{~cm})$, whereas Treatment B10H2S25 had the shortest plants $(74 \mathrm{~cm})$. Similarly, Treatment $\mathrm{B} 0 \mathrm{H} 2 \mathrm{~S} 25$ produced the highest number of tillers per hill (16.3), whereas the Treatment B10H1S20 (9.7) produced the lowest tiller number. All treatments significantly grew taller across sampling regimes.

Leaf area varied significantly among all the treatments $(\mathrm{P}<0.01)$ and sampling regime $(\mathrm{P}<0.001)$. Maximum leaf area was recorded in Treatment B0H2S25 $\left(36.1 \mathrm{~cm}^{2}\right)$, followed by Treatment B10H2S20 (34.9 $\left.\mathrm{cm}^{2}\right)$, while minimum leaf area was observed in Treatment B10H2S25 $\left(25.8 \mathrm{~cm}^{2}\right.$ ) (Figure 5). Overall, there was no significant difference in leaf area between the treatment and control.

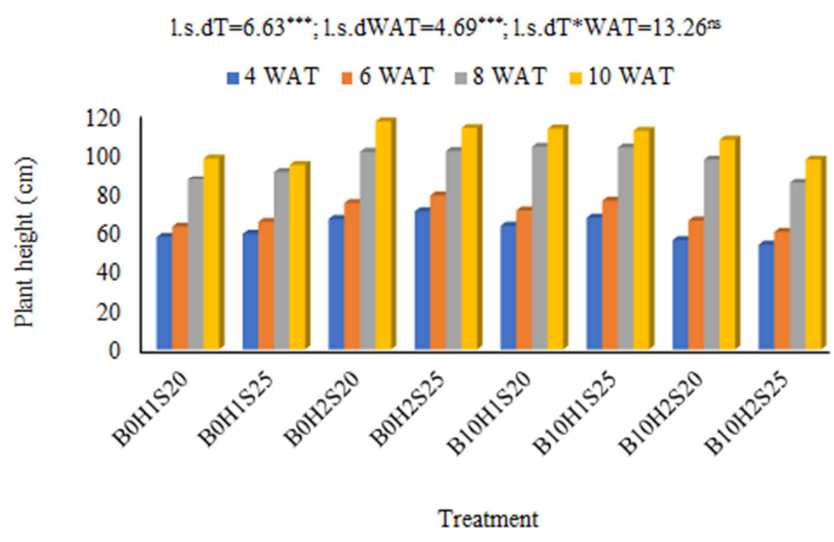

Figure 3. Effects of treatments on plant height sampled at 4, 6, 8 and 10 weeks after transplanting (WAT).

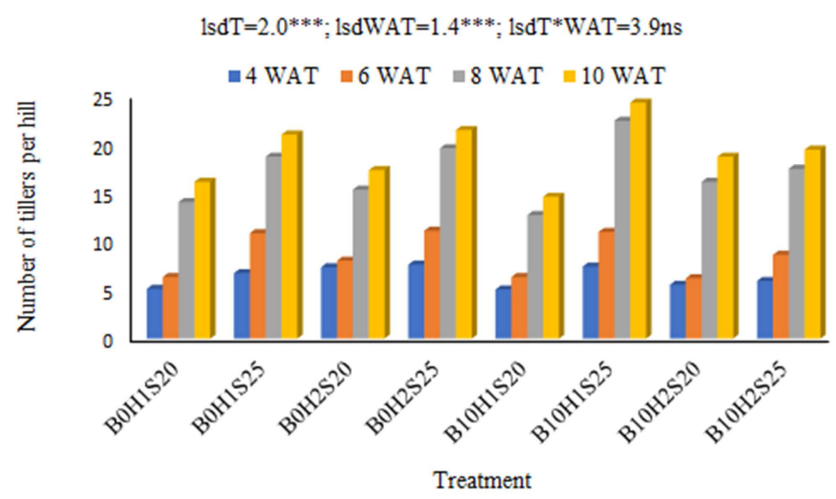

Figure 4. Effects of treatments on number of tillers per hill sampled at 4, 6, 8 and 10 weeks after transplanting (WAT).

This study examines the effect of biochar amendment, plant density and spacing on the growth of rice. Biochar amended plots partly enhanced growth parameters such as plant height, number of tillers per hill and leaf area. The increased plant height may be attributable to the 
improvement in soil physical and chemical properties. This is consistent with Masulili and Utomo [29], who reported that rice husk biochar amendment and $\mathrm{N}$ fertilizer application improved specific physical and chemical properties of the soil, which promotes aboveground vegetative growth. Also, previous studies have reported that biochar application with the addition of NPK fertilizer enhanced plant height [30-32]. Similarly, Lakitan et al. [33] noted that, biochar amendment increased plant height in a paddy field in Indonesia.

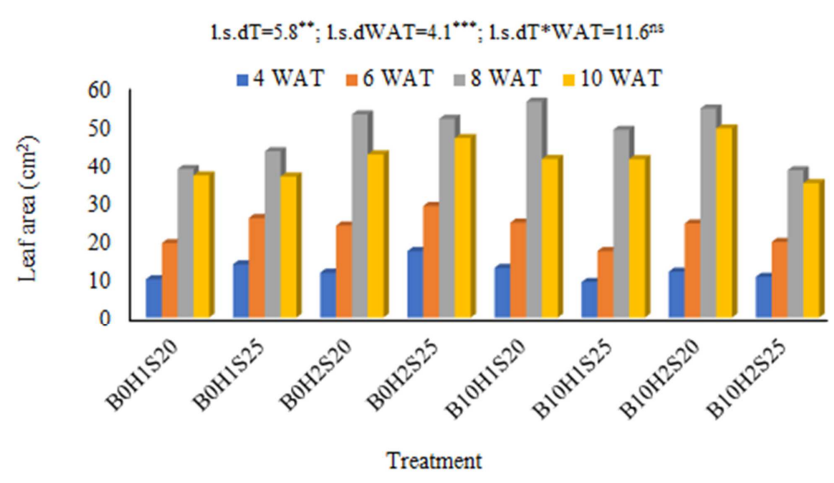

Figure 5. Effects of treatments on leaf area sampled at 4, 6, 8 and 10 weeks after transplanting (WAT).

There was a significant change in the number of tillers due to the applied treatment of different levels of biochar and plant spacing with no significant impact of biochar hill for the cropping season. Hence, there was a significant effect of plant spacing on tiller number in the treatment, with the highest tiller produced by Treatment B10H1S25, compared to the control. Liu et al. [34] used yield portion evaluation and noticed that the use of biochar in rice cultivation had a significant impact on productive tillers per hill, for two successive rice growing seasons in a waterlogged paddy field. In addition, an experiment conducted in Malaysia by Lai et al.
[32], noted that rice plants treated with $\mathrm{N}$ fertilizer and biochar treatments in a silt loam pot had a better response in terms of leaf area, plant height, leaf chlorophyll content (SPAD value), and tiller number compared to the control. Masulili and Utomo [29] reported in a study in Indonesia that the application of rice straw as soil amendment produced the highest number of tillers. The sole use of rice straw biochar improved rice plant height, tiller number, and dry biomass after eight weeks of planting [35].

\subsection{Yield and Yield Components}

Treatment exhibited no significant effects on the grain yield, straw yield and harvest index of rice (Table 2). However, the different treatments used significantly $(\mathrm{P}<0.001)$ influenced the numbers of panicle and spikelets produced. Treatments B10H2S20 and B0H2S20 had $0.66 \mathrm{t} \mathrm{ha}^{-1}$, while the lowest grain yield was recorded in Treatment B0H1S25 $\left(0.59 \mathrm{t} \mathrm{ha}^{-1}\right)$ (Table 2). Maximum straw yield was recorded in Treatment B10H2S20 (5.31 $\left.\mathrm{t} \mathrm{ha}^{-1}\right)$ followed by Treatment B10H2S25 (5.09 $\mathrm{t} \mathrm{ha}^{-1}$ ), while the minimum straw yield was recorded in the non-amended biochar Treatment B0H1S25 plot $\left(4.42 \mathrm{t} \mathrm{ha}^{-1}\right)$. Treatment B10H2S25 (0.127) exhibited the highest HI, whilst Treatment B0H1S20 (0.118) recorded the lowest. Treatments B0H1S25 produced the highest numbers of panicles (339.7) and spikelets (9.3), whereas B0H1S20 had the lowest of 181.1 and 6.9, respectively (Table 2). Treatments B10H2S20, B10H2S25 and B0H1S25 significantly produced the highest number of spikelets per panicle ranging from 8.7-9.3, whereas treatment B0H1S20 (6.9) exhibited the lowest number of spikelets. Treatments $\mathrm{B} 10 \mathrm{H} 1 \mathrm{~S} 20$ and B0H1S25 significantly produced highest number of panicles per meter square compared to the remaining treatments.

Table 2. Mean grain yield, straw yield, and yield components of rice grown under various biochar, plant density, and spacing at the inland valley swamp of Njala.

\begin{tabular}{|c|c|c|c|c|c|}
\hline Treatments & Grain yield (t ha $\left.{ }^{-1}\right)$ & Straw yield (t ha $\left.{ }^{-1}\right)$ & Harvest Index (HI) & Panicle Number $\left(\mathrm{m}^{-2}\right)$ & $\begin{array}{l}\text { Spikelet Number } \\
\left(\text { panicle }^{-1}\right)\end{array}$ \\
\hline B0H1S20 & $0.60 \mathrm{a}$ & $4.64 a$ & $0.118 \mathrm{a}$ & $181.7 \mathrm{f}$ & $6.9 \mathrm{f}$ \\
\hline B0H1S25 & $0.59 \mathrm{a}$ & $4.42 \mathrm{a}$ & $0.120 \mathrm{a}$ & $339.7 \mathrm{a}$ & $9.3 \mathrm{a}$ \\
\hline $\mathrm{B} 0 \mathrm{H} 2 \mathrm{~S} 20$ & $0.66 \mathrm{a}$ & $4.96 \mathrm{a}$ & $0.121 \mathrm{a}$ & $202.0 \mathrm{e}$ & $7.4 \mathrm{de}$ \\
\hline $\mathrm{B} 0 \mathrm{H} 2 \mathrm{~S} 25$ & $0.65 \mathrm{a}$ & $4.74 a$ & $0.124 \mathrm{a}$ & $324.7 \mathrm{bc}$ & $8.6 \mathrm{c}$ \\
\hline B10H1S20 & $0.61 \mathrm{a}$ & $4.99 a$ & $0.121 \mathrm{a}$ & $333.0 \mathrm{ab}$ & $8.5 \mathrm{c}$ \\
\hline B10H1S25 & $0.59 \mathrm{a}$ & $4.77 \mathrm{a}$ & $0.123 a$ & $266.7 \mathrm{c}$ & $8.2 \mathrm{~d}$ \\
\hline $\mathrm{B} 10 \mathrm{H} 2 \mathrm{~S} 25$ & $0.65 \mathrm{a}$ & $5.09 \mathrm{a}$ & $0.127 \mathrm{a}$ & $261.0 \mathrm{~cd}$ & $8.8 \mathrm{ab}$ \\
\hline Grand Means & 0.63 & 4.86 & 0.122 & 271.9 & 8.3 \\
\hline
\end{tabular}

Values with the same letters indicate that mean values are not significantly different from each other $(\mathrm{p} \geq 0.05)$, while different letters indicate that mean values are significantly different $(\mathrm{p}<0.05)$

\subsection{Regression Analysis for Measurement of Yield and Idts Attributing Traits}

There was a moderate positive relationship between the number of panicles per square meter and spikelet number per panicle $\left(\mathrm{R}^{2}=0.7465\right)$ (Figure $\left.6 \mathrm{a}\right)$, and between grain yield and straw yield $\left(\mathrm{R}^{2}=0.565\right)$ (Figure $\left.6 \mathrm{c}\right)$. Low positive relationship was found between grain yield and the number of panicles per square meter $\left(\mathrm{R}^{2}=0.0661\right)$ (Figure $\left.6 \mathrm{~b}\right)$; and between grain yield and harvest index $\left(\mathrm{R}^{2}=0.3377\right)$ (Figure $\left.6 \mathrm{~d}\right)$. The number of panicles $\mathrm{m}^{-2}$ contributed $74.65 \%$ and $6.61 \%$ to the variability observed in the number of spikelets per panicle, and the number of panicles $\mathrm{m}^{-2}$, respectively, while the remaining percentages were possibly due to environmental 
variation. Similarly, straw yield contributed $56.5 \%$ to the variability in grain yield. Grain yield contributed $33.77 \%$ to the variability in the harvest index.
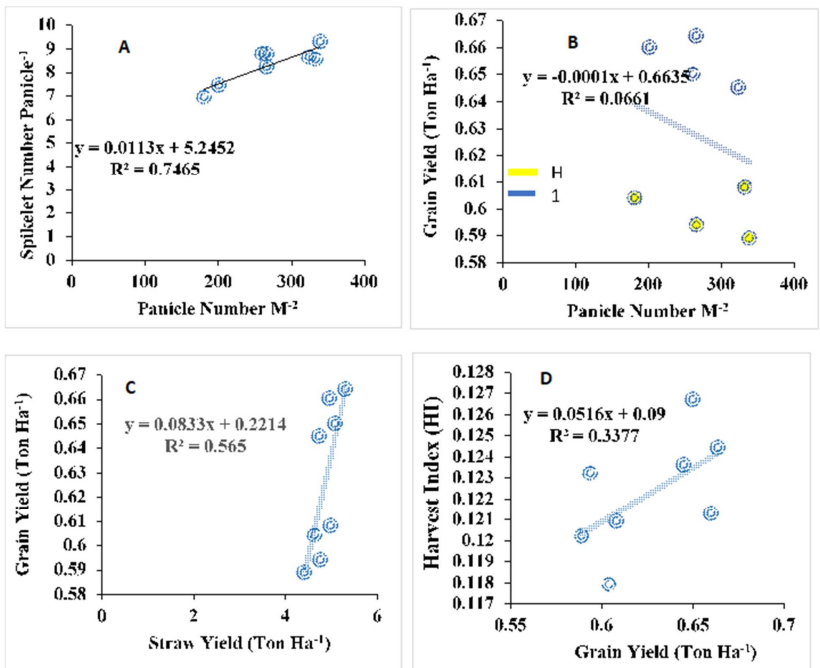

Figure 6. Relationships between (a) spikelet number per panicle and panicle number per square meter of rice; (b) grain yield in tons per hectare ( $t \mathrm{ha}^{-1}$ ) and panicle number per square meter of rice; (c) grain yield in tons per hectare ( $\left.h \mathrm{ha}^{-1}\right)$ and straw yield in tons per hectare; (d) grain yield in tons per hectare $\left(t h a^{-1}\right)$ and harvest index (HI) of rice.

Generally, gliricidia biochar application, plant density and spacing was found to enhance straw yield and related attributes in some treatments compared to the control, indicating the contribution of biochar in improving soil fertility that support growth and development of crops. Similarly, Zhao et al. [36] noted that seasonal application of $9 \mathrm{t} \mathrm{ha}^{-1}$ rice straw biochar with the standard fertilizer rate increased straw yield in both seasons, whereas increased grain yield was only achieved in the following season. The high grain yield in biochar amended plot partly corroborates with the findings of Si et al. [37], who found that biochar amendment and fertilizer $\left(180.0 \mathrm{~kg} \mathrm{~N} \mathrm{ha}^{-1}, 67.5 \mathrm{~kg} \mathrm{P}_{2} \mathrm{O}_{5}\right.$ ha ${ }^{1}$ and $67.5 \mathrm{~kg} \mathrm{~K}_{2} \mathrm{O} \mathrm{ha}{ }^{-1}$ ) significantly improves grains per panicle in a cold waterlogged paddy field. Oladele et al. [38], noted that rice husk biochar and inorganic fertilizer minimized soil nutrient leaching in tropical African rain-fed rice systems, thus making these nutrients more readily available for crop growth and increased grain yield. Hemwong and Cadisch [39] reported that biochar amendments and supplementary application of nitrogen fertilizer at the time of panicle initiation increased rice grain yield. Moreover, Jeffery et al. [40] conducted a metaanalysis that showed a significant positive impact of biochar application on crop yield, with a robust mean increase of $20-25 \%$ for tropical soils. Such improvement was related to a liming effect and enhanced soil water holding capacity, together with the increased availability of crop nutrients when biochar is applied to the soil. Another potential cause for the positive impacts of biochar is through the enhanced availability of soil nutrients, in which biochar applied to soil was found to enhance soil productivity [41-43]. Also, Chen et al. [44], revealed that biochar increased grains per panicle by facilitating the filling of rice grains under temperate climate conditions. Many studies have reported that biochar amendment with NPK fertilizer, improved rice growth and yield productivity [36, 45-47]. However, in the present study, the inconsistent performance of rice in terms of grain yields in biocharamended rice plots could be possibly attributable to the overuse of $\mathrm{P}$ fertilizer, high iron toxicity and inter-plot interference during the one season trial. These findings are partly supported by Xie et al. [48], who observed nosignificant impacts of biochar on rice yield in both fertile and infertile soil, which was possibly related to the overuse of $P$ fertilizer which could alter the chemical conditions of the biochar used. Similarly, Sui et al. [49] also indicated that there was no positive effect of rice straw biochar and $\mathrm{N}$ fertilizer on grain yield, which was ascribed to the lowtemperature region of Northeast China, where grain productivity was delayed.

\section{Conclusion}

The combined effects of various levels of gliricidia biochar amendment, plant density and spacing on the growth and yield of in inland valley swamp rice production was evaluated. The results indicate that there was higher grain yield in biochar fields (0.629-ton ha- 1 on the average) than that in non-biochar fields (0.625-ton ha-1 on the average). However, high plant density and minimum plant spacing had a greater positive effect on rice growth and yield parameters compared to lower plant density and maximum plant spacing in both biochar and non-biochar fields. Hence, there is a higher possibility of increased grain yield in greater plant densities and smaller plant spacing in favorable biochar paddy fields. The potential of gliricidia biochar in supporting increased growth and yield suggest its exploitation for both straw and grain yield productivity of rice in the IVS. Residual gliricidia biochar could be also exploited in future studies to determine their benefit in enhancing grain yield in IVS rice.

\section{Acknowledgements}

We are grateful for the support from the field technicians in the Department of Agricultural Engineering, School of Technology, Njala University, Sierra Leone.

\section{References}

[1] Muthayya, S., Sugimoto, J. D., Montgomery, S., and Maberly, G. F. (2014). An overview of global rice production, supply, trade, and consumption. Annals of the New York Academy of Sciences, 1324 (1): 7-14. https://doi.org/10.1111/nyas.12540.

[2] Rodenburg, J., Zwart, S. J., Kiepe, P., Narteh, L. T., Dogbe, W., and Wopereis, M. C. (2014). Sustainable rice production in African inland valleys: seizing regional potentials through local approaches. Agricultural Systems, 1; 123: 1-1. https://doi.org/10.1016/j.agsy.2013.09.004. 
[3] Adjao, R. T., and Staatz, J. M. (2015). Asian rice economy changes and implications for sub-Saharan Africa. Global Food Security, 5, pp. 50-55. https://doi.org/10.1016/j.gfs.2014.11.002.

[4] SLNSS, 2017. Sierra Leone National Nutrition Survey (SLNNS), 2017. $70 \mathrm{p}$.

[5] Li, T., Angeles, O., Radanielson, A., Marcaida, M., and Manalo, E. (2015). Drought stress impacts of climate change on rainfed rice in South Asia. Climatic change. 1; 133 (4): 709-20. https://doi.org/10.1007/s10584-015-1487.

[6] Tripathi, A., Tripathi, D. K., Chauhan, D. K., Kumar, N., and Singh, G. S. (2016). Paradigms of climate change impacts on some major food sources of the world: a review of current knowledge and prospects. Agriculture, Ecosystems \& $\begin{array}{llll}\text { Environment. } & 15 ; & 216: & 356-73 .\end{array}$ https://doi.org/10.1016/j.agee.2015.09.034.

[7] Rajakamar, R., and Jayasree Sankar, S. (2016). Biochar for sustainable agriculture - A Review. International Journal of Applied and Pure Science and Agriculture, 2016, 2 (9): 173184.

[8] Woolf, D., Amonette, J. E., Street-Perrott, F. A., Lehmann, J., and Joseph, S. (2010). Sustainable biochar to mitigate global climate change. Nature communications. 10; 1: 56. https://doi.org/10.1038/ncomms1053.

[9] Chan, K. Y., Van Zwieten, L., Meszaros, I., Downie, A., and Joseph, S. (2008). Agronomic values of green waste biochar as a soil amendment. Soil Research, 45 (8), pp.629-634. https://doi.org/10.1071/SR07109.

[10] Spokas, K. A., Cantrell, K. B., Novak, J. M., Archer, D. W., Ippolito, J. A., Collins, H. P., Boateng, A. A., Lima, I. M., Mekuria, W., and Noble, A. (2013). The role of biochar in ameliorating disturbed Soils and sequestering soil carbon in tropical agricultural production systems. Apple. Environ. Soil Sci., 1-10.

[11] Zornoza, R., Moreno-Barriga, F., Acosta, J. A., Muñoz, M. A., and Faz, A. (2016). Stability, nutrient availability, and hydrophobicity of biochars derived from manure, crop residues, and municipal solid waste for their use as soil amendments. Chemosphere, 144, 122-130. https://doi.org/10.1016/j.chemosphere.2015.08.046.

[12] Schulz, H., and Glaser, B. (2012). Effects of biochar compared to organic and inorganic fertilizers on soil quality and plant growth in a greenhouse experiment. Journal of Plant Nutrition and Soil Science, 175, 410-422. https://doi.org/10.1002/jpln.201100143.

[13] Ding, Y., Liu, Y., Liu, S., Li, Z., Tan, X., Huang, X., Zeng, G., Zhou, L., and Zheng, B. (2016). Biochar to improve soil fertility. A review. Agronomy for sustainable development. 1; 36 (2): 36. https://doi.org/10.1007/s13593016-0372-z

[14] Mukherjee, A., and Lal, R. (2013). Biochar impacts on soil physical properties and greenhouse gas emissions. Agronomy, 3, 313-339. https://doi.org/ 10.3390/agronomy3020313.

[15] Paz-Ferreiro, J., Plasencia, P., Gascó, G., and Méndez, A. (2017). Biochar from pyrolysis of deinking paper sludge and its use in the remediation of $\mathrm{Zn}$ - polluted soils. Land Degradation \& Development, 28, 355-360. https:// doi.org/10.1002/ldr.2597.
[16] Jeffery, S., Verheijen, F. G. A., van der Velde, M., and Bastos, A. C. A. (2011). Quantitative review of the effects of biochar application to soils on crop productivity using meta-analysis. Agriculture, Ecosystems, and Environment, 144, 175-187. https://doi.org/10.1016/j.agee.2011.08.015.

[17] Ali, S., Rizwan, M., Qayyum, M. F., Ok, Y. S., Ibrahim, M., Riaz, M., Arif, M. S., Hafeez, F., Al-Wabel, M. I., Shahzad, A. N. (2017). Biochar soil amendment on alleviation of drought and salt stress in plants: a critical review. Environmental Science and Pollution Research, 24 (14), pp. 12700-12712. https://doi.org/10.1007/s11356-017-8904-x.

[18] Liu, X., Zhang, A., Ji C., Joseph, S., Bian, R., Li, L., Pan, G., and Paz-Ferreiro, J. (2013). Biochar's effect on crop productivity and the dependence on experimental conditions - a meta-analysis of literature data. Plant and soil. 1; 373 (1-2): 583-94. https://doi.org/10.1007/s11104-0131806-x.

[19] Zhou, Y., Berruti, F., Greenhalf, C., Tian, X., and Henry, H. A. L. (2017). Increased retention of soil nitrogen over winter by biochar application: implications of biochar pyrolysis temperature for plant nitrogen availability. Agriculture, Ecosystems \& Environment. 236: 61-68. https://doi.org/10.1016/j.agee.2016.11.011.

[20] Hunter, B., Cardon, G. E., Olsen, S., Alston, D. G., and McAvoy, D. (2017). Preliminary screening of the effect of biochar properties and soil incorporation rate on lettuce growth to guide research and educate the public through extension. Journal of Agricultural Extension and Rural Development. $\quad 9 \quad 1$ (1): https://doi.org/10.5897/JAERD2016.0787.

[21] Smith, J. L., Collins, H. P., and Bailey, V. L. (2010). The effect of young biochar on soil respiration. Soil Biology and $\begin{array}{lllll}\text { Biochemistry. } & 1 ; & 42 & (12): & 2345-7 .\end{array}$ https://doi.org/10.1016/j.soilbio.2010.09.013.

[22] Lehmann, J., Gaunt, J., and Rondon, M. (2006). Biochar sequestration in terrestrial ecosystems-a review. Mitigation and adaptation strategies for global change. 11 (2): 403-27. https://doi.org/10.1007/s11027-005-9006-5.

[23] Biederman, L. A., and Harpole, W. S. (2013). Biochar and its effects on plant productivity and nutrient cycling: a metaanalysis. GCB Bioenergy, 5: 202-214. https://doi.org/10.1111/gcbb.12037.

[24] Ogle, S. M., Breidt, F. J., and Paustian, K. (2005). Agricultural management impacts on soil organic carbon storage under moist and dry climatic conditions of temperate and tropical regions. Biogeochemistry 72 (1): 87-121. https://doi.org/10.1007/s10533-004-0360-2.

[25] Barrow, C. J. Biochar: (2012). Potential for countering land degradation and for improving agriculture. Applied Geography, 34, pp. 21-28. https://doi.org/10.1016/j.apgeog.2011.09.008.

[26] Brewer, C. E. (2012). Biochar Characterization and Engineering. Graduate Theses and Dissertations, Paper 12284. Iowa State University, Ames, IA, USA. Available online: http: //lib.dr.iastate.edu/etd (accessed on 4 February 2019). https://doi.org/10.31274/etd-180810-2233.

[27] Conteh, A. M. H., Yan, X., and Moiwo, J. P. (2015). The determinants of grain storage technology adoption in Sierra Leone. Cashier Agric. 24, 47-55. https://doi.org/10.1684/agr.2015.0733. 
[28] Food and Agriculture Organization of the United Nations (FAO). Food and Agricultural Organization forest resources assessment 1990: tropical countries. FAO Forestry 1993, Paper No. 112. Rome, Italy.

[29] Masulili, A., Utomo, W. H., and Syechfani, M. S. (2010). Rice husk biochar for rice-based cropping system in acid soil 1. The characteristics of rice husk biochar and its influence on the properties of acid sulfate soils and rice growth in West Kalimantan, Indonesia. Journal of Agricultural Science. 2 (1): 39.

[30] Gathorne-Hardy, A., Knight, J., and Woods, J. (2009). Biochar as a soil amendment positively interacts with nitrogen fertilizer to improve barley yields in the UK. In IOP Conference Series: Earth and Environmental Science (Vol. 6, No. 37, p. 372052). IOP Publishing. https://doi.org/10.1088/1755-1307/6/7/372052.

[31] Dong, D., Feng, Q., Mcgrouther, K., Yang, M., Wang, H., and Wu, W. (2015). Effects of biochar amendment on rice growth and nitrogen retention in a waterlogged paddy field. Journal of Soils and Sediments. 15 (1): 153-62. https://doi.org/10.1007/s11368-014-0984-3.

[32] Lai, L., Ismail, M. R., Muharam, F. M., Yusof, M. M., Ismail, R., and Jaafar, N. M. (2017). Effects of rice straw biochar and nitrogen fertilizer on rice growth and yield. Asian Journal of Crop Science. 9 (4): 159-66. https://doi.org/ 10.3923/ajcs.2017.159.166.

[33] Lakitan, B., Alberto, A., Lindiana, L., Kartika, K., Herlinda, S., and Kurnianingsih, A. (2018). The benefits of biochar on rice growth and yield in tropical riparian wetland, South Sumatra, Indonesia. CMUJ Natural Sciences. 17 (2): 111-26. https://doi.org/10.12982/CMUJNS.2018.0009.

[34] Liu, Y., Lu, H., Yang, S., and Wang, Y. (2016). Impacts of biochar addition on rice yield and soil properties in a cold waterlogged paddy for two crop seasons. Field Crops Research. 1 1; 191-7. https://doi.org/10.1016/j.fcr.2016.03.003.

[35] Kamara, A., Kamara, H. S., and Kamara, M. S. (2015). Effect of rice straw biochar on soil quality and the early growth and biomass yield of two rice varieties. Agricultural Sciences. 6 (08): 798. DOI: $10.4236 /$ as.2015.68077

[36] Zhao, X., Wang, J., Wang, S., and Xing, G. (2014). Successive straw biochar application as a strategy to sequester carbon and improve fertility: A pot experiment with two rice/wheat rotations in paddy soil. Plant and soil. 378 (1-2): 279-94. https://doi.org/10.1007/s11104-014-2025-9.

[37] Si, L., Xie, Y., Ma, Q., and Wu, L. (2018). The short-term effects of rice straw biochar, nitrogen and phosphorus fertilizer on rice yield and soil properties in a cold waterlogged paddy field. Sustainability. (2): 537. https://doi.org/10.3390/su10020537.

[38] Oladele, S. O., Adeyemo, A. J., and Awodun, M. A. (2019). Influence of rice husk biochar and inorganic fertilizer on soil nutrient availability and rain-fed rice yield in two contrasting

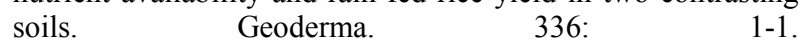
https://doi.org/10.1016/j.geoderma.2018.08.025.
[39] Hemwong, S., and Cadisch, G. (2012). Effects of Biochar Amendment on Soil Fertility and Lowland Rice Yield in Nakhon Phanom Province Northeast Thailand. The Journal of the $8^{\text {th }}$ National Agriculture Department 2012; pp. 45-48.

[40] Jeffery, S., Abalos, D., Prodana, M., Bastos, A. C., Van Groenigen, J. W., Hungate, B. A., and Verheijen F. (2017). Biochar boosts tropical but not temperate crop yields. Environmental Research Letters. 12 (5): 053001.

[41] Ghoneim, A. M., and Ebid, A. I. (2013). Impact of rice-straw biochar on some selected soil properties and rice (Oryza sativa L.) grain yield. International Journal of Agronomy and Agricultural Research 3: 14-22.

[42] Peng, X. Y., Ye, L. L., Wang, C. H., Zhou, H., and Sun, B. (2011). Temperature-and duration-dependent rice strawderived biochar: Characteristics and its effects on soil properties of a Ultisol in southern China. Soil and Tillage Research. $\quad 112 \quad$ (2): $159-66$. https://doi.org/10.1016/j.still.2011.01.002.

[43] Wu, W., Yang, M., Feng, Q., McGrouther, K., Wang, H., Lu, H., and Chen, Y. (2012). Chemical characterization of rice straw-derived biochar for soil amendment. Biomass and Bioenergy. 47 268-76. https://doi.org/10.1016/j.biombioe.2012.09.034.

[44] Chen, Y., Zhang, M., Liu, X., Dai, G., and Hou, S. (2016). Effects of biochar on chlorophyll fluorescence at full heading stage and yield components of rice. Crops. 94-98.

[45] Steiner, C., Teixeira, W. G., Lehmann, J., Nehls, T., de Macêdo, J. L., Blum, W. E., and Zech, W. (2007). Long term effects of manure, charcoal and mineral fertilization on crop production and fertility on a highly weathered Central Amazonian upland soil. Plant and soil. 291 (1-2): 275-90. https://doi.org/10.1007/s11104-007-9193-9.

[46] Zhang, A., Bian, R., Pan, G., Cui, L., Hussain, Q., Li, L., Zheng, J., Zheng, J., Zhang, X., Han, X., and Yu, X. (2012). Effects of biochar amendment on soil quality, crop yield and greenhouse gas emission in a Chinese rice paddy: a field study of 2 consecutive rice growing cycles. Field Crops Research. 127: 153-60. https://doi.org/10.1016/j.fcr.2011.11.020.

[47] Vinh, N. C., Hien, N. V., Anh, M. T., Lehmann, J., and Joseph, S. (2014). Biochar treatment and its effects on rice and vegetable yields in mountainous areas of northern Vietnam. International Journal of Agricultural and Soil Science. 2 (1): $5-13$.

[48] Xie, Z., Xu, Y., Liu, G., Liu, Q., Zhu, J., Tu, C., Amonette, J. E., Cadisch, G., Yong, J. W., and Hu, S. (2013). Impact of biochar application on nitrogen nutrition of rice, greenhousegas emissions and soil organic carbon dynamics in two paddy soils of China. Plant and Soil. 370 (1-2): 527-40. https://doi.org/10.1007/s11104-013-1636-x.

[49] Sui, Y., Gao, J., Liu, C., Zhang, W., Lan, Y., Li, S., Meng, J., $\mathrm{Xu}, \mathrm{Z}$., and Tang, L. (2016). Interactive effects of strawderived biochar and $\mathrm{N}$ fertilization on soil $\mathrm{C}$ storage and rice productivity in rice paddies of Northeast China. Science of the Total Environment. 203-10. https://doi.org/10.1016/j.scitotenv.2015.11.079. 